Article

\title{
A Contribution to the Sustainable Development of Maritime Transport in the Context of Blue Economy: The Case of Montenegro
}

\author{
Jelena Nikčević *(i) and Maja Škurić (i) \\ Faculty of Maritime Studies Kotor, University of Montenegro, 85330 Kotor, Montenegro; mskuric@ucg.ac.me \\ * Correspondence: jelenag@ucg.ac.me; Tel.: +382-32-303-184
}

check for updates

Citation: Nikčević, J.; Škurić, M. A Contribution to the Sustainable Development of Maritime Transport in the Context of Blue Economy: The Case of Montenegro. Sustainability 2021, 13, 3079. https://doi.org/ $10.3390 /$ su13063079

Academic Editor: Tianming Gao

Received: 14 January 2021

Accepted: 5 March 2021

Published: 11 March 2021

Publisher's Note: MDPI stays neutral with regard to jurisdictional claims in published maps and institutional affiliations.

Copyright: (c) 2021 by the authors. Licensee MDPI, Basel, Switzerland. This article is an open access article distributed under the terms and conditions of the Creative Commons Attribution (CC BY) license (https:// creativecommons.org/licenses/by/ $4.0 /)$.

\begin{abstract}
Maritime transport and sustainable development require a recognizable global approach. The state, as the dominant structure in the world, enables the realization of sustainable maritime transport aims through its instruments. Therefore, it is very significant to consider the national maritime policies because the effective implementation of the global policy is impossible without considering the adequate mechanisms at the state level. The adopted Montenegrin strategic documents impact the institutional framework set-up of the Blue Economy (BE) sectors and potentials for ecologically sustainable maritime transport. Although there are no practical directions for the sustainable use of sea resources, Montenegro is affirmatively oriented to the BE concept. Knowing that Montenegro is in the process of the pre-accessing EU phase, it is of importance to be on the right road to creating a national maritime transport policy including environmental practices, to become part of the strategic implementation of the BE. The paper provides recommendations that can serve for the successful follow-up of the BE activities in Montenegro and the wider area.
\end{abstract}

Keywords: sustainability; Blue Economy (BE) sectors; maritime transport; legislative framework

\section{Introduction}

It is almost needless to discuss the importance of ocean spaces. For a long time, it was seen that the sea represented an inexhaustible natural resource that we aimed to use indefinitely. On the contrary, due to natural events and human actions, the sea is a resource exposed to numerous dangers of its sustainability. Therefore, the Blue Economy (BE) concept appeared as a "pillar of protection" of the unsustainable use of sea resources.

The relatively new term BE has been used in various world studies as a comprehensive set of economic activities concerning the sea and promoting the context of sustainable development of the country or region. The main aim of the BE is to provide economic prosperity using sea resources whose realization only makes sense if marine resources are used sustainably. Sustainable use of marine resources is a complex phenomenon that requires an interdisciplinary approach. It means considering and establishing the optimal relationship between environmental, economic, and sociological factors of marine resources. In order to overcome the gap between economic prosperity and the need for the sustainability of marine resources, the ecological dimension is significant because it emphasizes the establishment of efficient sea resources management that includes a number of activities; in the first place, preventing marine pollution, protecting the marine and coastal ecosystems, stimulating regulated fishing, conserving coastal and marine areas, employing the new marine technologies, and acknowledging scientific background [1].

Besides that, the BE also includes the activities on the innovation principles in the development and application of new information technologies, digitalization of the logistics chains, alternative energy sources, new port infrastructure, and the orientation to transport intermodality, etc [2]. 
In recent literature, there have been different approaches in identifying the concept and problems found within BE as well as the solutions to overcome them. Further, there is a mismatch between the theory and practice in providing sustainable BE, representing one of the problems that urge for the proactive, systematic, and bold policies and actions needed to provide an environmentally sustainable and socially equitable BE [3]. From the cost-effectiveness point of view, it was elaborated the importance of understanding the economic benefit of the ocean-based economy and creation of national measurable data for following the employment, wages, establishments, and output [4,5]. In addition, it was pointed out the importance of the economic, societal, and environmental performances of maritime transport through the legislative framework review to provide a broader European initiative for the BE implementation [6]. On the other hand, one of the main issues in the global understanding of the BE term is the distinction in four prominent discourses of human-ocean relations [7]. Similarly, the problematic existence of different understandings of what the BE represents within the Caribbean Community led to compromise on the agreed policy and strategy that would effectively coordinate and operationalize BE development [8]. The researchers indicated the presence of ambiguities related to BE and offered solutions for its overcoming.

Although figuring out the related problems and the complexity of BE, many coastal countries and small-island developing states (SIDS) also see promise in ocean-based growth. Montenegro, located in southeast Europe, also recognizes the perspective in ocean resources, but it encounters doubts in the formulation and popularization of official policy and practice, oriented towards sustainable Blue Growth. Having it in mind, this paper tries to respond to some mentioned issues without experiencing the economic contribution of the BE sectors in the national economy. Therefore, there are two main objectives of the paper: first, to contribute to the strategic steps for engaging the concept of BE to the relevant government bodies that adopted the corresponding documentation and recommendations of ecologically sustainable marine transport development policy and integrated coastal area management; and second, to indicate to the governing bodies the importance of the practical dimension of BE implementation, especially maritime transport as one of the $\mathrm{BE}$ sectors and its ecological aspect, in the sense of key performance monitoring and smooth development.

This paper is structured as follows. The related literature on the BE concept is given in Section 2. The methodology of the research work is shown in Section 3. The empirical analysis of Montenegrin strategic documents and existing maritime administration for the BE activities are reported in Section 4. Section 5 elaborates the status and trends (supported by numerical data) of the BE sectors in Montenegro. Section 6 provides the scientific provisions for ecologically sustainable maritime transport activities including a statistical overview of achieved throughput in Montenegrin ports, and a legislative framework systemized through the two levels (global/regional, and national ones). The final discussion and recommendations are specified in the concluding remarks.

\section{Literature Review}

The term BE was first popularized in scholarly literature through Pauli [9] as the title of a book he authored which discussed moving society from scarcity to abundance by pioneering advances which replicate the waste-free efficiency of ecosystems [8]. Kildow and McIlgorm [4] used the term ocean economy to point out the studies that measured the economic benefit of the oceans and coasts by explaining that the highest losses in marine transport and coastal tourism are related to fuel costs and climate change, respectively. Also, in Colgan [5] the methodology for estimation of the ocean and coastal economic activities in the case of the Great Lakes in the US was investigated. The author used data series and identified the areas and actions for further development. The potential for the maritime transport sector of the BE is presented in Niavis et al. [6]. The authors gave, inter alia, the legislative framework through the analysis of maritime transport related to the Adriatic-Ionian region. 
The implications of the BE are described in a study by Henderson [10]. The essential point is the sustainable development of coastal areas through the marine cultural heritage and benefits that act as a result of the implementation of the BE principles. A new study addressing various economic activities of oceans and seas with the background of the EU policy framework, initiatives, and actions related to the BE is explained in Scholaert et al. [11]. Chen et al. [12] examined the best practices of BE in coastal communities in China, Samoa, and Vietnam and the relationship between poverty and the environment. It is concluded that in obtaining the productivity of these communities, a more proactive approach should be dedicated to natural resource management. Lee et al. [13] examined the challenges and opportunities in the BE that are in line with the United Nations' Sustainable Development Goals (SDG). They noticed the gap between key stakeholders and their roles in the $\mathrm{BE}$, and through the analysis of the literature review during the 21-year observed period, concluded that key stakeholders need to be concentrated more on the prosperous range for the ocean biosphere. Silver et al. [7] investigated the level of the BE employment concept in global environmental governance while prioritizing ocean problems, solutions, and participants. They pointed out the option of unreliable discourse existence between different actors within the maritime economy. Andriamahefazafy et al. [14] identified the contradiction within the current fisheries' policies, as one of the main sectors of the $\mathrm{BE}$, in the islands of Madagascar, Mauritius, and Seychelles, emphasizing the practical ecological preservation that should be taken into account while providing the positive socio-ecological trends and implicit growth.

Reading the article by Bennett et al. [3] in the form of a comment provided in the Nature Sustainability Journal, on the global rush to develop the BE concept, it is concluded that the synergy between the social equity and environmental sustainability of the BE is urgently needed. Moreover, the article contains a proactive approach to implement systematic policies and bold actions based on interdisciplinary ocean science and inclusive governance processes. On the other hand, Christodoulou and Woxenius [15] explained the role of short sea shipping (SSS) in the frame of sustainable maritime transport. Referring to Europe, challenging areas for contribution to the scientific investigations are related to the Mediterranean, North Sea, and Baltic Sea and their modes of sustainable maritime transportation. The emphasis of the study is to provide more empirical analysis in the sense of improving sustainable maritime transport of SSS. Tirumala and Tiwari [16] assessed the current world initiatives and projects for the BE development elaborating features of the financing instruments for relevant stakeholders in the area. For example, in the case of the European Union, the most convenient strategy is the Blue Growth from 2012 and the report on the "Blue Growth Strategy Toward More Sustainable Growth and Jobs in the Blue Economy" prepared by the EU in 2017 [17]. Referring to the coastal and marine tourism sector, the incomes are identified from cruises, hotels, and resorts. In the case of ports and the shipping sector, the benefits are the results of the sale of products or services.

Through a literature review in this domain, some investigations deal with the BE in the context of sustainable development of specified regions. The World Bank and United Nations Department of Economic and Social Affairs in the report from 2017 [18] defined a sustainable BE as the activity that provides social and economic benefits of marine resources and marine ecosystems. Moreover, numerous international regulations require the shipping industry to invest significantly in environmental technologies, covering issues such as emissions, waste, and ballast water treatment. The International Maritime Organization (IMO) as a key organization for the BE sector outlines the safe, secure, efficient, and reliable maritime transport of goods within world trade satisfying the requirements for environment protection [19]. The statistics show that this sector of the BE comprises both operations at sea and ports counting around $25 \%$ of all international trade [1].

Toward the annual report on the EU BE, six established sectors comprise the sustainable development of oceans, seas, and coastal resources: extraction of marine living resources, offshore oil and natural gas, ports, warehousing and construction of water projects, shipbuilding and repair, maritime transport, and coastal tourism. Maritime trans- 
port includes sea and coastal passenger water transport, sea and coastal freight water transport, inland passenger water transport, inland freight water transport, and renting and leasing of water transport equipment. Sea and coastal passenger water transport include both passenger ferry services and cruise passengers [20]. Also, coastal tourism alongside the accommodation segment covers the transport sub-sector that comprises sea and coastal passenger water transport. Quantitative results from the study reported by EUNETMAR [21] indicate that the first and second most promising activities in the Adriatic and Ionian Seas are maritime transport and coastal tourism.

Similar analysis about the status of the BE sectors in the Mediterranean including marine natural ecosystems and maritime resources is related to coastal tourism, fisheries and aquaculture, maritime transport and port activities, shipbuilding and recycling, energy (offshore), bioprospecting, and deep-sea mining [1]. According to the BLUEMED [2] report delivered in 2018, the Mediterranean Sea represents a very dynamic crossroad with approximately $20 \%$ of the total world's maritime transport.

A special overview on the Adriatic-Ionian region is covered by the EU Strategy for the Adriatic-Ionian Region (EUSAIR) where the European Commission specified the opportunities in the development of the maritime economy [17]. Referring to the updates in the number of the participating countries, this consortia includes four EU Member States (Croatia, Greece, Italy, and Slovenia) and five non-EU countries (Albania, Bosnia and Herzegovina, Montenegro, North Macedonia, and Serbia) [22]. Each state belongs to the appropriate pillar such as Blue Growth, Connecting the Region, Environmental Quality, and Sustainable Tourism.

This paper addresses two segments: to scientifically contribute to the adoption of marine policies in Montenegro and recommend the governing bodies the on-time actions in the sustainable development of the BE.

\section{Methodology}

The available literature, books, scientific and professional articles obtained through bibliographic research served as a methodological starting point for preparing this paper. It is based on three research methods: document analysis, systematic review, and case study.

We begin with the empirical overview of the Montenegrin strategic documents in Section 4 (the document analysis method) specifying the engaged relevant bodies for the implementation of the BE activities that were provided in the Strategy for the development of the maritime industry for the period 2020-2030 (SDMI) [23] and National Strategy for Sustainable Development until 2030 (NSSD) [24] as a precondition for understanding the concept of the sustainable use of the Montenegrin coastal area. The qualitative observation of the relevant documents contains the most important implications in the BE sectors elaborated in the following method.

The rising question of identification of the BE sectors, an overview of the scientific and legal regime (where applicable), critical appraisal of sectors' development and trends, and data presentation were a subject of the systematic review method. Indeed, this is the first analysis that comprehends all Montenegrin BE sectors in one place providing the historical background, economic parameters, statistical data, and legal policies. Section 5 contains:

- $\quad$ the economic contribution of BE in Montenegro;

- the total investments in coastal tourism and tourists' achievements with its contribution of the total gross domestic product (GDP) and national employment level;

- $\quad$ realized and planned capital infrastructure projects that directly or indirectly impact the BE;

- $\quad$ the current initiatives to develop small shipyards for leisure boats, yachts, and megayachts, application of biotechnologies aiming at environmental protection;

- $\quad$ the scientific background of the fisheries sector especially the small coastal fishing and its impact on GDP and national employment, potentials of mariculture, and;

- the international negotiations in the exploration of oil and natural gas as a novel sector in the country giving the review of the adopted regulations. 
The specific emphasis is on the maritime transport sector applying the case study method is presented in Section 6. It is distributed through the four directions:

- the review of importance of the maritime transport national and regional scientific investigations in the prism of its environmental sustainability in Montenegrin ports; - the statistical background of economic activities achieved by cargo and passenger ships throughput and nautical tourism vessels;

- the overview of the global legal framework on the protection of the marine environment from pollution and the status of its adoption in Montenegrin legislation and;

- the relevant national regulations for maritime transport and ecologically sustainable use of the sea.

The research methods used in this paper aim to address the specific research question: Is there any gap between marine policy and practice, and what actions are needed?

\section{Montenegrin Strategic Documents and Maritime Administration in the Context of BE}

In this section, we provide an empirical and critical view on relevant strategic documents that have direct and indirect implications for the development of BE sectors in Montenegro in the context of sustainable use of the sea. Here we consider: National Strategy for Sustainable Development until 2030 (NSSD) [24]; National Strategy for Integrated Coastal Area Management from 2015-2030 (NSICAM) [25]; Strategy for the development of maritime industry for the period 2020-2030 (SDMI) [23] and Transport Development Strategy-Montenegro 2019-2035 (TRDS) [26].

As it is not the focus to go through a detailed analysis, we elaborated few strategies in the context of assessing the dedication of Montenegro in the direction of sustainable use of marine resources and the development of the BE. Indeed, NSICAM represents an integral part of NSSD such that both strategies deserve special attention. NSICAM is the umbrella and long-term development strategy of Montenegrin society. The adoption of NSICAM was preceded by another document-National Sustainable Development Strategy in 2007 (NSDS) [27] that included guidelines for Montenegrin sustainable development and recognizes the ecological vision as a key aspect for sustainable development. In 2016, Montenegro adopted the NSSD, which seeks to improve the policy of sustainable development and ensure effective control and prevention of pollution. The goal of the NSSD strategy is aimed at the sustainable development of Montenegrin society through the consideration of four types of resources: human, social, natural, and economic. The strategy recognizes the coastal area resources as a developed opportunity of the BE and adequate resources management, treating $\mathrm{BE}$ development as a strategic goal. The document identified the coastal ecosystem as one of the most endangered systems. The reasons for this are numerous pressures on the environment starting from excessive urbanization and infrastructure development in the coastal area, which leads to the conversion of natural habitats into built-up areas. The expansion of cruising tourism leads to a large increase in the number of visitors including accompanying maritime transport activities, which implies an increase in environmental pollution, such as the spread of invasive species resulting in higher ballast water discharges. Furthermore, the pollution control system and natural resources management are recognized as a big problem and are of great concern. The strategy correctly notes that there are not enough valid data on monitoring the effects of environmental pollution i.e., there is a lack of analysis of the impact of increased concentrations of certain pollutants on the local population, as well as estimates of total damage which threatens the economy due to environmental pollution. To overcome this and preserve the coastal area, the use of mechanisms and instruments for sustainable management of coastal resources is of key importance. In that sense, the specific emphasis is related to creating conditions for diversification of the economy in the coastal area and stopping uncontrolled urbanization.

The orientation towards the BE is evident in NSICAM, which defines a strategic framework for sustainable development of the Montenegrin coast through the integra- 
tion of spatial and developed solutions aimed at advancing the economic, social, and environmental performances of the coastal area. Moreover, this strategy underlines the importance of integral and coherent management of Montenegrin coastal area resources including: natural (the sea, water, land, and space), economic (primarily in agriculture, fishery, maritime transport, and shipbuilding), social capital (interconnections and cooperation between social actors), and human resources (knowledge and abilities). Besides, in the sea, other economic activities are performed such as bathing and nautical tourism, maritime transport, shipbuilding, fishery, and mariculture. It is recognized that the sea offers possibilities for economic activities which are currently not developed in Montenegrobiotechnology, exploitation of living and inanimate components of the marine environment for pharmaceutical purposes, exploitation of minerals, and others.

In 2020, Montenegro adopted the SDMI document. The main aim of the Strategy is to define the directions of the maritime economy in Montenegro and adequately valorize the potentials of the sectors through the prism of the BE activities. The Strategy covers almost all economic activities related to the sea. The strategic goals of the document are related to increasing the contribution and growth of the economy, strengthening the capacity of the maritime administration, greater involvement of the civil sector, and the inclusion of the professionals as a precondition for a prosperous maritime economy. The Strategy foresees a Montenegrin maritime cluster establishment that would include all national bodies, public authorities, business actors, etc. Despite the positive assessment adopting this act (which is the first act of its kind in Montenegro), we believe that the Strategy has certain shortcomings. One of the high omissions is the very conceptual setting of this document, i.e., the broader approach during its formation. The broader approach leads to the perception of different segments of the maritime economy of Montenegro in a very restrictive, i.e., superficial way. Furthermore, the lack of measures or insufficient analysis to achieve strategic goals will be an aggravating factor for implementing the Strategy. In addition, we believe that much more attention should be paid to the examination of the economic and social aspects of the maritime economy, precisely aiming for its better development.

In the context of our research, we present a TRDS strategy that determines the situation in the field of transport, defines the goals of the development of the transport system that is realized through implementation plans. Ecological sustainability is envisaged as a strategic goal, which is observed through carbon dioxide emissions reduction and the impact on the natural, historical and socio-economic environment. The Strategy presents the maritime transport sector through an overview of the existing infrastructure and shipping fleet of Montenegro while neglecting the consideration of safety and protection of the marine environment as a dimension of sustainable maritime transport.

To conclude this part shortly, we single out three more strategies that converge to the $\mathrm{BE}$ sectors identified in the following section. The most important aspect of the Fisheries Strategy of Montenegro 2015-2020 [28] is related to the identification of the key steps for the integration of Montenegro in Common Fisheries Policy (CFP). The projected goal of the Tourism Development Strategy in Montenegro until 2020 [29] is to create a sustainable, high quality, and diverse tourism product that will enable the growth of income and the growth of the number of tourists, and through that create new jobs and increasing living standards. The Energy Development Strategy of Montenegro to 2030 specifies the plan for energy development within the regulations of the Energy Policy of Montenegro to 2030 adopted in 2011 [30].

Referring to the jurisdiction of relevant bodies responsible for the implementation of the BE activities, we specify three levels of Montenegrin maritime administration in Figure 1. The first level is related to the four ministries with a focus on the competencies of each body individually according to SDMI in 2020 [23]. The Ministry of Transport and Maritime Affairs is the umbrella institution for drafting laws and bylaws, systemic solutions, defining policies, and implementing maritime affairs. These activities are implemented through the Directorate of Maritime Economy and the Directorate of Maritime Transport and Inland Waterways (that represents the second level of competencies). The last one, through its 
four units, follows the implementation of maritime safety standards, standards for the sea pollution prevention and inland navigation, supervision in international and inland waterways transport, and harbors offices in Bar and Kotor (included in the third level of competencies). Also, the Administration for Maritime Safety and Port Management performs tasks related to the safety of navigation in the coastal area of Montenegro as well as other tasks assigned to its competence.

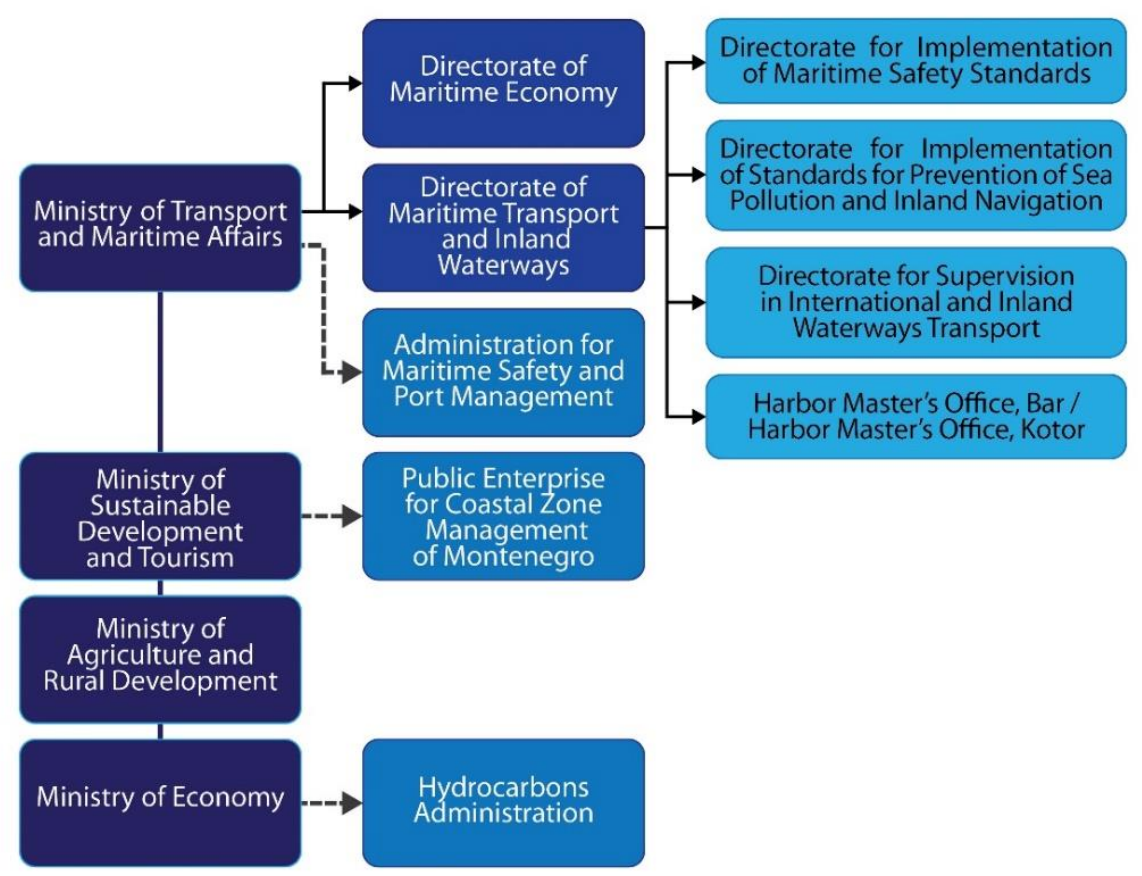

Figure 1. Montenegrin maritime administration in the context of the Blue Economy (BE) by 2020.

Within a Ministry of Sustainable Development and Tourism, there is a Public Enterprise for Coastal Zone Management of Montenegro (positioned at the second level) that manages all maritime infrastructure facilities (ports, docks, moorings, etc.). This body established the functional unit for the integral management of the maritime domain area and infrastructure facilities. The sustainability of the management system (protection, arrangement, and improvement), marine assets, and maritime infrastructure facilities, has been achieved by reinvesting the funds earned by the concession fee incomes.

The Ministry of Agriculture and Rural Development is responsible for the fisheries and mariculture sector. The Ministry of Economy founded the Hydrocarbons Administration (the second level) and delegated the responsibility for the implementation of the Energy Development Strategy of Montenegro to 2030 [30].

\section{BE Sectors in Montenegro: Status and Trends}

According to the published data in the SDMI [23], there were 488 active business entities registered in the field of $\mathrm{BE}$ in 2018. The growing number of business entities indicates a growing interest in this area. In contrast to that, the $\mathrm{BE}$ accounted for $0.6 \%$ of Montenegro's GDP, which is the lowest level in five years. Besides, the average number of employees was 1502 persons, which represent $0.8 \%$ of employees in the country. The mentioned trends are the result of the business of larger companies in this area. The overall economic contribution of the BE from 2014 to 2018 is given in Table 1 [23]. 
Table 1. Economic contribution of BE in Montenegro [23].

\begin{tabular}{cccccc}
\hline & $\mathbf{2 0 1 4}$ & $\mathbf{2 0 1 5}$ & $\mathbf{2 0 1 6}$ & $\mathbf{2 0 1 7}$ & $\mathbf{2 0 1 8}$ \\
\hline No. of business entities & 336 & 379 & 390 & 417 & 488 \\
Average no. of employees & 1971 & 1778 & 1592 & 1481 & 1582 \\
Gross Value Added (million $€$ ) & 29.5 & 27.9 & 26.8 & 30.2 & 27.2 \\
\% in GDP & 0.9 & 0.8 & 0.7 & 0.7 & 0.6 \\
\hline
\end{tabular}

The importance of the sea waters is priceless for small countries such as Montenegro (with a total coast length of $289 \mathrm{~km}$ ). Its geographic position provides some advantages compared to the countries that are not entering the sea and cannot use the potentials in maritime transport, coastal tourism, capital infrastructure projects and shipbuilding and repair, fisheries and mariculture, and offshore oil and natural gas for economic development.

In the following analysis, we identify Montenegrin BE sectors as well as the most important legislative framework and strategic documents. Regarding the maritime transport sector, a detailed overview will be provided in the next section.

\subsection{Coastal Tourism}

Coastal tourism includes tourism and beach recreation (e.g., swimming, surfing, etc.) and other recreational activities in coastal areas. According to statistical data, 85\% of tourist arrivals and 95\% of total overnight stays happened in coastal places [23]. The distribution of the number of tourists' statistics and the type of the region visited are given in Tables 2 and 3, respectively [31].

Table 2. Percentage of the increase in the number of tourists' arrivals and overnights for the period 2014-2019 [31].

\begin{tabular}{cccccc}
\hline & $\mathbf{2 0 1 5 / 2 0 1 4}$ & $\mathbf{2 0 1 6 / 2 0 1 5}$ & $\mathbf{2 0 1 7 / 2 0 1 6}$ & $\mathbf{2 0 1 8 / 2 0 1 7}$ & $\mathbf{2 0 1 9 / 2 0 1 8}$ \\
\hline Tourists arrival & 11.4 & 5.9 & 10.3 & 10.2 & 20.00 \\
Overnights & 13.6 & 1.8 & 6.3 & 8.2 & 11.8 \\
\hline
\end{tabular}

Table 3. Percentage of the total number of tourists' arrival by the type of region [31].

\begin{tabular}{cccccc}
\hline & $\mathbf{2 0 1 5 / 2 0 1 4}$ & $\mathbf{2 0 1 6 / 2 0 1 5}$ & $\mathbf{2 0 1 7 / 2 0 1 6}$ & $\mathbf{2 0 1 8 / 2 0 1 7}$ & $\mathbf{2 0 1 9 / 2 0 1 8}$ \\
\hline Coastal region & $\mathrm{n} / \mathrm{a}$ & 76 & 94.9 & 94.9 & 94.9 \\
Other & $\mathrm{n} / \mathrm{a}$ & 24 & 5.1 & 5.1 & 5.1 \\
\hline
\end{tabular}

The number of tourists' arrivals increased every year, i.e., from 1.5 million in 2014 to 2.6 million in 2019 [31]. Analogously, in 2014 there were a total of 9.5 million overnights while in 2019, it increased to 14.4 million overnights. From Table 3, it is evident that from 2017 almost $95 \%$ of the total number of tourists that are visiting Montenegro are located in the coastal region.

The total investment in tourism is approximately 30\% of total financing every year [25]. The coastal tourism in Montenegro relies on mass swimming tourism with natural beaches and clean bathing water, while coastal transport represents a type of touristic service. The coastal transportation is active for touristic purposes (consisting of bathers and excursion tours) and taxi boat transport during the summer season on one side, and ferry transport in function of intercity traffic performed in a year. Besides the existing transportation along the coast in the previous period, Montenegro adopted regulations in 2019 followed by making changes and amendments to the Law on Maritime Navigation Safety [32].

Coastal tourism activity contributes $15 \%$ of the GDP of Montenegro, and it employs $27 \%$ of people in the country [33]. The operation goal within SDMI [23] is to build new marinas and modernize the existing ones. In the last ten years, the total number of international vessels increased by $67.8 \%$. There is no official evidence for recreational 
tourism. The coastal area is the most economically developed part of Montenegro. Slightly higher activity rate $(51.6 \%$, which is $1.5 \%$ higher than the national average) and lower unemployment rate $(8.4 \%$, which is $11 \%$ lower than the national average) are correlated with a higher degree of economic development. The coastal area, known for its natural values and cultural heritage, is of special interest in the development of tourism. Over the past several years, more than $95 \%$ of the total tourist traffic in Montenegro (measured by realized overnight stays) took place in the coastal area [25,31].

\subsection{Capital Infrastructure Projects and Shipbuilding and Repair}

In terms of activities, the most significant growth was recorded in the construction sector with an increase in infrastructure works of 31.5\%, while investments in fixed capital recorded an increase of $21.5 \%$, as a result of infrastructure projects and projects in the fields of energy and tourism. The total estimated share of gross investment and exports of goods for 2018 is estimated at $73.4 \%$ of GDP (an increase from $62.2 \%$ in 2015). This shows that the goals of economic policy aimed at the growth of investments and exports of goods and services are being achieved [26].

If we observe the priority projects of the transportation infrastructure that directly or indirectly impact the BE sectors, the first place is related to the construction of the highway Bar-Boljare; the second place refers to the modernization of the rail infrastructure, and the third priority project is directed to the increase of the number of shipping lines. According to the Regional Development Strategy of Montenegro 2014-2020 (RDS) [34], almost 4 billion $€$ was planned to be invested in nine projects: a touristic complex in Kumbor, the Plavi horizonti resort, the Montenegro-Italy submarine cable, Luštica bay resort, Porto Montenegro, Maoče coal mine, the second block of thermal power station Pljevlja, the Kotor-Lovćen-Cetinje cable car, and the first part of the Bar-Boljare highway.

Referring to the maritime transport and nautical tourism activities, there are some small ports, marinas, and resorts that are mostly built: Porto Montenegro as an exclusive yachting marina (invested approximately 550 million $€$ ), Porto Novi (invested approximately 545 million $€$ ), Marina Lazure (invested approximately 25 million $€$ ), Dukley Marina and other small ports in the Boka Kotorska Bay, partially reconstructed marina Bar, constructed Luštica Bay resort (until now approximately 26 million $€$ have been invested).

Projected capital infrastructure projects from 2020 include a new container terminal in the Port of Bar, an extension of passenger and bulk cargo terminals in the Port of Bar, increasing the operational capacity in the Kotor cruise port and Marina Kotor, purchasing of new ships within "Barska plovidba AD" and "Crnogorska plovidba AD Kotor", renewal of the Ro-Ro line between Montenegro and Italy [23,35]. From the fisheries and mariculture sector, some constructions and equipping are projected for the fishing ports of Ulcinj, Bar, and Herceg Novi [23].

According to Petrick et al. [1], it is suggested that one of the promising marine and maritime activities in Montenegro is related to shipbuilding and ship repair. The history covers almost one hundred years of the ship repair activities of the biggest repair yard in the Southern Adriatic called "Bijela". But, following the trends and Montenegrin orientation towards nautical and coastal tourism, the shipyards are finding potential in relation to the construction and repair of leisure boats, yachts, and mega yachts.

NSICAM [25] promotes the EU integrated maritime policy from 2008 dealing with sustainable maritime transport and shipbuilding, including short sea shipping, Ro-Ro transport, and local coastal transport. One of the measures and sub-measures is to emphasize the application of new materials and biotechnologies in the sense of protecting the environment caused by technological operations in shipbuilding, repairs, and yacht sustainability. The hot spot locations are proposed and comprised of current shipyards. Additionally, NSSD [24] in Montenegro defines the strategic goal SDG $9(9.4,9.5)$ that provides remediation of existing pollution and builds infrastructure for waste and wastewater treatment. It is referred to as shipyard "Bijela" and other small shipyards. 
The use of small vessels is also present in Montenegrin coasts for leisure activities and daily charter, as well as taxi and excursion boats, etc. Currently, the most popular shipyards are a couple of small yards located in the Boka Kotorska Bay, and Bar. Some of them are traditional shipyards for the wooden boats used to improve environmental performances of coastal tourism and maritime transport [1]. Besides, the construction of hybrid solar vessels is also occurring at the shipyards, their building satisfies the environmental requirements providing easy maintenance especially in the Boka Kotorska Bay.

A strategic effort in research and innovation in green shipbuilding and energy-efficient ships should represent a significant part of the BE in Montenegro in the future. It will follow the recommendations described in Petrick et al. [1] and the EUSAIR document [22] that promotes a national strategy to develop potential synergies between shipbuilding and ship repair, yachting, and marinas [33]. Shipyards in Montenegro are oriented to vessels for sports and leisure activities, and the need to provide conditions for a regular and extraordinary overhaul of maritime inland waterway vessels in Montenegro is recognized [23].

\subsection{Fisheries and Mariculture}

This sector was scientifically treated and we present an overview on the actualities within fisheries and mariculture in Montenegrin waters beside others in the Adriatic. First, we emphasize the research work of Cobani et al. [36] that reported a study by the FAO AdriaMed Working Group on small-scale fisheries (SSFs), which has identified the gaps and priorities for the fisheries sector in the observed region. This research is followed up by the recent scientific work of Grati et al. [37] that considered the seasonal dynamics of the set gears. They observed regional small-scale fisheries including Montenegro and collected the data (landings, fishing effort, the composition of catches, and length-frequency distributions of target species and economic value of landings) on target species.

Rajović and Bulatović [38] analyzed some geographic aspects of fisheries of Montenegro emphasizing that the total catch of marine fish by species was 741 tons, while the catch of freshwater fish amounted to 838 tons representing a lack of potential development in this sector of Montenegro. Joksimović et al. [39] contributed to the literature in the reported area and reviewed the state of marine fisheries in Montenegro for the last 15 years. On the other hand, Matić-Skoko et al. [40] gave specific conclusions for the coastal resources in the SSFs domain in Croatia and Montenegro. The authors proposed additional measurements and the active management of the fisheries. Finally, they demonstrated some advances in collecting data methodology. Joksimović et al. [41] completed the study on the ecosystem risk identifying the concentration of individual metals and metalloids for the ten years at precise locations along the Montenegrin coast.

The fisheries sector is treated as an important economic activity that has the potential for development [23]. According to the analysis reported in FS [28], this sector is not developed at a satisfactory level while the dominant activity is related to the small coastal fishing. The fishing fleet accounts for up to $80 \%$ of small-scale coastal fishing vessels. According to the Statistical Office of Montenegro (MONSTAT) data for 2019, the fishing fleet consists of a total of 244 vessels which is a significant increase in the fishing fleet compared to 2016 when it consisted of a total of 135 vessels [35]. The share of the fisheries sector in Montenegro results in $0.5 \%$ of the GDP whereas the number of employees in the fisheries sector is 400; on the other hand, the total catch of fish along the Montenegrin coast is approximately 700 to 800 tons per year [24].

The fisheries sector has started to intensively follow the Montenegrin pre-accession negotiations with the EU in order to meet the requirements of the EU CFP. This is most evident through the adoption of legal instruments for the sustainable management of living marine resources and the regulation of overall fisheries policy, as well as through the foundation of an institutional framework for the fisheries sector. In that sense, the basic regulations in Montenegro that stipulate the sustainable management of biological resources, i.e., hunting, breeding, and protection of fish and other organisms in sea and 
freshwater based on the principles of sustainable development are: the Law on Marine Fisheries and Mariculture [42] and the Law on Freshwater Fisheries and Aquaculture [43]. In addition to the current situation in this sector, there are still a number of problems, primarily an outdated and inefficient fishing fleet, lack of adequate coastal infrastructure (fleet port, first landing sites, first sale sites), illegal fishing, and lack of appropriate market channels for the sale, etc [42].

Mariculture activities that have the potential for natural development, benefits, and cultivation but are not completely used are presented especially within the seaside of the Boka Kotorska Bay in Montenegro, as reported by the Institute of Marine Biology of the University of Montenegro. The cultivation of shellfish is also at a low level in relation to the natural potentials. At a total of 17 farms, which are also located in the Boka Kotorska Bay, the current annual production of mussels in 2017 was 197 tons, while the amount of oysters farmed is still negligibly small and yields about 17 tons [23]. One of the main reasons for the insufficient development of the mariculture sector is that there are no new breeding sites, especially those on the high seas. Therefore, it is necessary to improve the examination of the potential of the high seas from the aspect of strengthening fisheries and mariculture, and in the context of diversification of economies [24].

\subsection{Offshore Oil and Natural Gas}

Exploration of oil in the Montenegrin underwater area has been especially actualized from the 2010s. In 2011, Montenegro defined an area (blocks) for exploration and production of hydrocarbons, while in 2013 it published the first public call for the award of contracts for concessions for exploration and production of hydrocarbons. In 2014, the Ministry of Economy adopted the Energy Development Strategy of Montenegro to 2030. According to official data, Montenegro does not have oil and natural gas reserves [30]. From 2016, two concession agreements have been concluded for the production of hydrocarbons; the first one was signed in 2016 with a consortium consisting of the company Eni Montenegro BV and the company Novatek Montenegro BV. The second contract was signed a year later with the company Energean Montenegro LTD. The benefits of the research, which are one of the obligations of the concessionaire, are related to the fee payment for the concession area. The collected data on the payment concession fee for all three concessionaires benefited Montenegro with an income of 2.1 million $€$ from 2016 to 2020 [44].

The Montenegro Hydrocarbon Administration of the Government of Montenegro represents the institution responsible for all affairs relevant to the exploration and production of hydrocarbons. It also supervises the execution of the concession contract for the production of hydrocarbons by the side of concessionaires [44]. The country adopted the regulations which ensure the successful implementation of research of the underwater area, without negative effects. The key Montenegrin laws of importance for the exploration and production of hydrocarbons are: the Law on Exploration and Production of Hydrocarbons [45] and the Law on Tax on Hydrocarbons [46]. The Draft Law on Safety Measures for Exploration and Production of Hydrocarbons in the underwater area is in the preparation phase which should implement Directive 2013/30/EU on the safety of underwater operations [47].

Regarding natural gas, in February 2020 there were media announcements of the potential communication between the American and Montenegrin companies in the field of storage and distribution of natural liquefied natural gas from the United States of America to Montenegro [48].

\section{Analysis of Maritime Transport and Legislative Framework in Montenegro 6.1. Research Work on the Topic of Sustainable Maritime Activities}

The overview on the research works dated since 2014 on the topic of providing the sustainable environmental maritime (transport, logistics, and other coastal) environment in Montenegro without mentioning the BE concept, served as an incentive for deeper analysis 
of its economic impact simultaneously providing ecological solutions and environmental preservation of the coastal region, having in mind the increased level of maritime traffic and other coastal activities.

The Montenegrin UNESCO protected site, the Boka Kotorska Bay, was a subject of numerous scientific investigations related to the environmental sustainability of maritime transport (cruise and ferry) in the last decade. The study on the Boka Kotorska Bay in the sense of air pollution implications has been done by Nikolić et al. [49]. The quantification of cruise ship exhaust emission at cruising, maneuvering, and hoteling regimes was reported. The results showed that more than $70 \%$ of the total emission from cruise ships was related to the hoteling mode while providing recommendations for its reduction. A comparative analysis in the level of emission from cruise ships and their externalities between Dubrovnik cruise port in Croatia and Kotor cruise port in Montenegro was reported in Dragović et al. [50]. The estimation of air pollution indicated the infrastructure solutions (such as an extension of the main berth's length) for reducing the emission inventories and the level of damage costs.

In the study of Nikčević [51], the author identifies the problems that Montenegro is facing on the pathway to achieve full membership within the Paris Memorandum of Understanding on Port State Control (Paris MoU), as a legal instrument that hugely contributes to the sustainable maritime transport in Montenegro. At the same time, the author gives guidelines on whether to improve the inspection supervision in the sea of Montenegro to become a full member of the Paris MoU. Moreover, observing the comprehensive legislative, administrative, technical, and financial resources, Nikčević [52] stipulated that the local authorities should pay more attention to avoid the possible intensive pollution and constitute sustainable tourism to the Kotor cruise port. The economic sustainability of passenger ferry transport in the case of the Boka Kotorska Bay in Montenegro is reported in Škurić et al. [53]. The study shows that with the appropriate assignment of the ferry fleet, the operator achieves increased profit. Also, the estimation of emission inventories of nitrogen oxides (NOx), particulate matter ( $\mathrm{PM})$, sulfur dioxide $\left(\mathrm{SO}_{2}\right)$, and carbon monoxide (CO) produced by passenger ferry services that are transporting tourists inside the Boka Kotorska Bay in Montenegro during a peak season was discussed. The proposals for emission reduction solutions are provided in Škurić et al. [54].

Ivanović and Bauk [55] developed a holistic multi-phase logistics model for six coastal towns in Montenegro while taking into account the specifics of centers of these towns, which are confined and with limited connectivity with the main road, real, sea transportation, and delivery channels. The simulation results provided in the analysis showed the possibility of achieving greater economic and environmental effects. Vitić-Ćetković and Bauk [56] positioned the Port of Kotor on the digital map of leading cruise ports in Europe and highlight online informative and transactional functions that should improve the Port of Kotor's visibility and approachability for the visitors through its website. Bauk et al. [57] dealt with port worker's occupational safety at the Port of Bar container terminal developing a model of advanced vehicle-to-everything (V2X) communication network at the physical and link layers, based on 5G technology to enhance workers traceability and avoid accidents within the port environment. It should contribute better positioning of Port of Bar among "safe" and "green" ports in the Mediterranean. Kapidani et al. [58] compared maritime business and safety info-communication systems available and used in Montenegro and other neighboring EU and non-EU countries. They highlighted the weaknesses of Montenegro's "fit-out" in this regard comparing with EU countries and proposed recommendations for improvements towards enhancing maritime sustainability.

\subsection{The Sector of Maritime Transport}

The total value of imported goods within maritime transport in 2018 amounted to 3.5 million $€$ (compared to 2 million $€$ in 2014; 3.3 million $€$ in 2015 and 2017, respectively), while exports of goods achieved around 1.8 million $€$. The only deviation was recorded in 2017, when there was a surplus in the exchange of goods with foreign countries in the 
amount of more than 10 million $€$, as a result of the sale of the docks of the "Bijela" shipyard. In the structure of imports, the trade of yachts and other vessels for sports and leisure activities is the most represented [23].

Also, there is a surplus in maritime transport services. In 2018, the surplus based on the mentioned services amounted to 40.5 million $€$. The total revenues from maritime transport services amounted to 60.1 million $€$, while expenditures amounted to 19.6 million $€$. In the total revenues of maritime transport, other transport activities account for $88.4 \%$ of the revenues, freight transport $11.5 \%$, while revenues from passenger transport are negligible with only $0.1 \%$. On the other hand, in the structure of expenditures of maritime transport, the largest share of $52.8 \%$ belongs to other transport activities and $46.1 \%$ is related to freight transport, while expenditures based on passenger transport counted $1.1 \%$ [23].

Looking back to the 1980s, Montenegro was one of the republics within Yugoslavia where maritime transport benefits played an important role. At the time as Lloyd reported, the Yugoslav shipping trade fleet ranked 27th in the world. This result is achieved by two Yugoslav shipping companies located in Montenegro "Prekookeanska plovidba" from Bar and "Jugooceanija" from Kotor and included 44 ships in their fleet in 1988 that provided huge incomes for the state and Montenegro. It provided a profit of about 100.000 million \$ realizing the transport of 900,000 ship gross tonnages [59].

The political situation in the 1990s implied the disintegration of Yugoslavia and the national shipping companies did not operate and remained without the income of the shipping fleet. The result of this situation was indeed unfavorable for the country and shipping companies from Montenegro went bankrupt. From 2006 when Montenegro claimed independence, the intention was to revitalize maritime transport through the establishment of two shipping companies in Bar and Kotor ("Barska plovidba AD" and "Crnogorska plovidba AD Kotor") for operating with bulk cargo.

With reference to maritime activities, there are six ports in Montenegro included for international transport: Bar, Kotor, Zelenika, Budva (only in the summer season), Tivat, and Risan. The biggest port in the country is the Port of Bar, and the second phase of the port area was constructed in 1971. It was projected to realize the throughput of 5 million tons per year. From 2009, the Port of Bar completed the restructuring process and was divided into two companies: Container Terminal and General Cargo AD_from 2013 Port of Adria $\mathrm{AD}$ as a multipurpose port with dedicated terminals for container ships, general cargo ships, Ro-Ro, and cruise ships [60], and Port of Bar AD [61]. The total realized throughput of goods in Montenegrin ports observing the period 2014-2019 is given in Table 4.

Table 4. The statistics of achieved throughput in Montenegrin ports [31].

\begin{tabular}{cccc}
\hline Year & Throughput in Ports in Tons & Transshipped Tons in Ports & Manipulated Tons in Ports \\
\hline 2014 & $1,241,431$ & $1,787,101$ & $2,760,042$ \\
2015 & $1,488,399$ & $1,650,776$ & $3,369,942$ \\
2016 & $1,645,797$ & $1,617,518$ & $3,696,210$ \\
2017 & $2,096,122$ & $2,324,336$ & $3,673,312$ \\
2018 & $1,963,204$ & $1,989,023$ & $3,293,338$ \\
2019 & $2,050,869$ & $2,023,183$ & $4,032,266$ \\
\hline
\end{tabular}

As evident, there was an increase in 2017 and 2019 of cargo throughput with more than 2 million tons, respectively. Regarding the transshipped tons of goods for the same period, certain transshipment is presented for 2014, 2015, 2016, and 2018. Finally, the maximum level of manipulated tons was reached in 2019 [31]. On the other hand, RoRo passenger throughput at the ferry line between Bar (Montenegro) and Bari (Italy) was: in 2014 the traffic volume reached 42,489 passengers, during 2015 the indicator was 39,198 passengers and in 2016, a total of 35,925 passengers were transported [31]. From 2017 the official Montenegrin operator canceled the line and afterward, the Croatian Ro-Ro ship was chartered only during the summer season. 
The share of profit achieved by the Port of Bar AD in 2016 was 1.3 million $€$; 0.94 million $€$ in 2017; 0.3 million $€$ in 2018, and 0.93 million $€$ in 2019 indicating the fluctuations in the business activities of the port. It included the income from the combination of port services, fishing, shipping, cruise tourism, and other activities [62].

The cruising sector is experiencing high yearly growth in the last decade. Kotor cruise port is the third port after Venice and Dubrovnik in the Adriatic Sea regarding the number of port calls achieved in a year [63]. However, the region is recognized as an attractive cruise destination. The statistics on the number of port call and passengers (pax) on-board cruise ships is given in Figure 2. As can be seen, the number of port calls faced an increase until 2016 while there was a slight decrease in the number of port callings from 2017 to 2019. On the other hand, the enhanced throughput of passengers was predominant every year except in 2018 when there was an unusual decrease in the number of tourists that came to Kotor by cruise ships [31]. According to the official financial reports of the Port of Kotor, the achieved profit in 2016 was 0.912 million $€ ; 0.927$ million $€$ in 2017; 0.795 million $€$ in 2018 , and 1.1 million $€$ in 2019 [64].

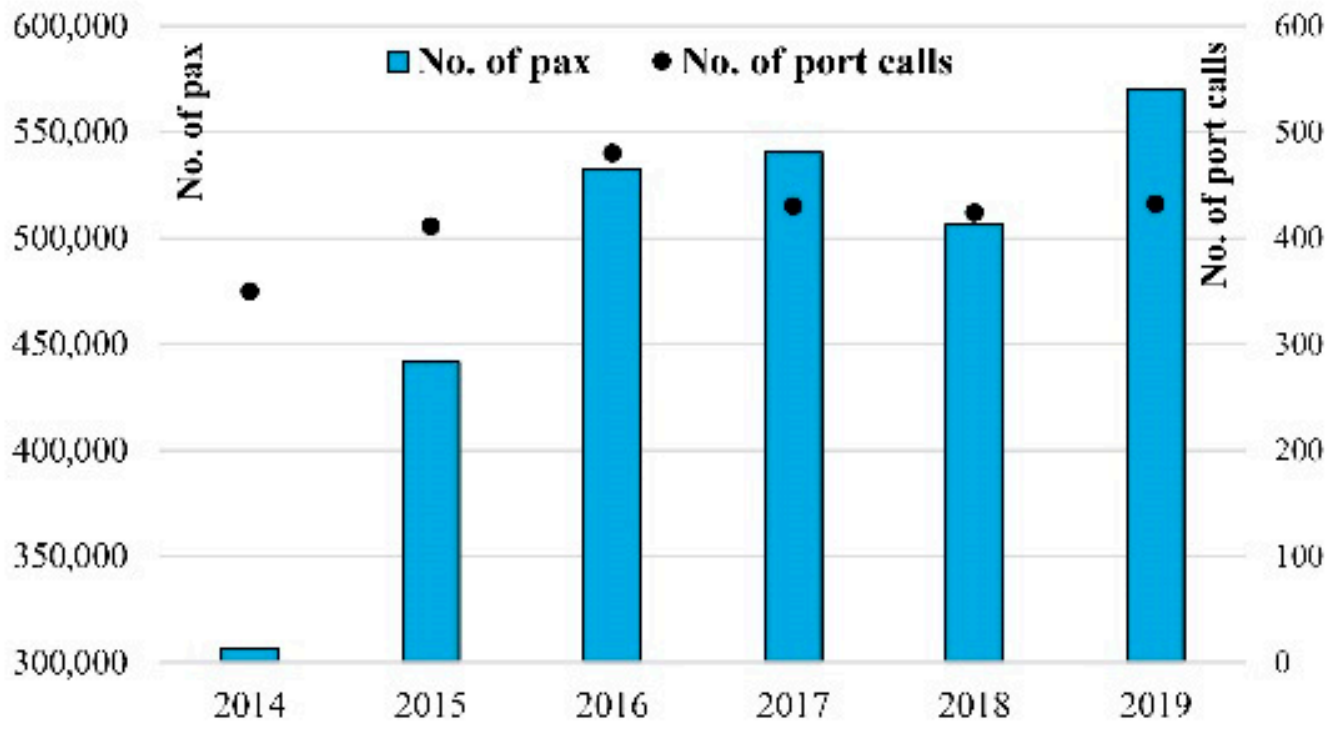

Figure 2. The cruise ships' throughput statistics [31].

Nautical tourism activities are recognized as very attractive ones along the coast of Montenegro. The expansion of marinas is related to leisure activities and a lot of yachts and other touristic vessels are coming to small nautical ports such as Porto Montenegro, Porto Novi, Marina Bar, Marina Budva, Marina Škver, Marina Kotor, etc. Montenegro adopted the Law on Yachts in 2007 [65] which in one place, using the best international legal solutions, regulates the nationality, identification, registration, navigation, yachts stay, and rental conditions in the Montenegrin waters. This law establishes a special yacht register-the Montenegro Yachts Register. Every yacht can be entered in this register, regardless of whether it is owned by a foreign or domestic citizen (yacht owner) [66]. Speaking of the impact of nautical tourism activities in Montenegro, from Figure 3 there is an evident constant increase both in the total number of vessels that visited Montenegrin territorial waters and the number of passengers on-board those vessels. The coast region of Montenegro is on the nautical map of these activities and often represents a favorite destination during the summer. For example, an average of $5.9 \%$ of the yearly increase happened in the case of the number of vessels. In the case of passengers, there is a higher increase on an average of $12.4 \%$ every year [31].

Assuming the inconceivable consequences that unsafe maritime transport would have in the coastal area for all sectors of the BE, as well as for the entire state of Montenegro, 
and beyond, we opted for a more detailed review of the legislative framework of maritime transport considering regulations related to the environmental sustainability.

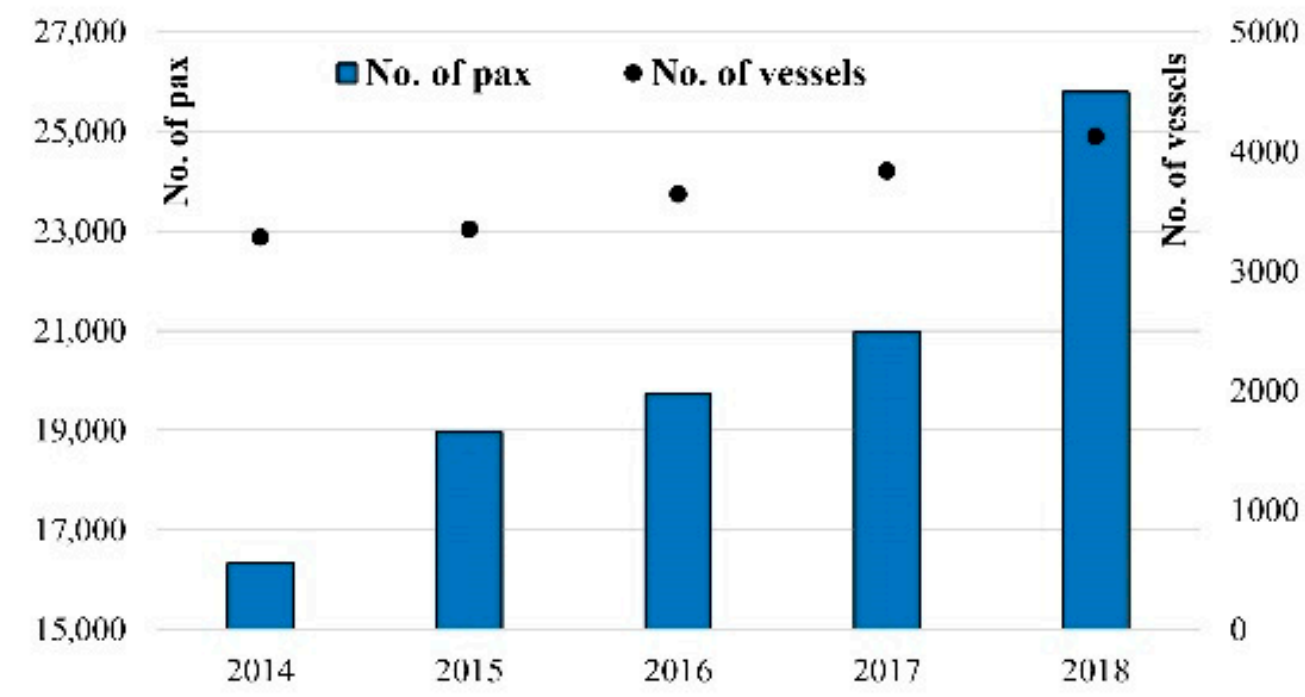

Figure 3. The statistics of nautical tourism vessels and passengers [31].

In order to obtain a sustainable development of maritime transport, it must not have an adverse impact on the marine environment, i.e., its negative impacts should be minimized. Consequently, in compliance with regulations related to maritime safety and protection of sea pollution from vessels represent a prerequisite and imperative for sustainable maritime transport. In this section, first, we identify the international regulations that represent the global framework for the protection of the sea and Montenegro's adoption status. Afterward, the Montenegrin regulations are important for maritime transport and ecologically sustainable use of the sea.

\subsection{International Regulations}

The protection of the marine environment from pollution has, for many years, been placed under the priority activities of several international organizations. This section emphasizes the activities in the direction of the implementation of legal regulations.

The UN Convention on the Law of the Sea-UNCLOS, represents the "umbrella treaty" considering the legal framework governing the rights and responsibilities of nations in their use of ocean space. Part XII of UNCLOS (Articles 192 to 237) regulates the protection and preservation of the marine environment including the area that stipulates the right of innocent passage through the territorial sea, sea areas, settlement of disputes, etc. Although the primary responsibility of the flag state for ships flying its flag is to control the pollution, the Convention also foresees certain powers for coastal states and port states to protect the marine environment. In addition to the UNCLOS, there are numerous international conventions on the protection of the marine environment adopted under the auspices of the IMO.

The global legal framework divided into three criteria (prevention from sea pollution, legal framework to eliminate and reduce harmful consequences, and legal framework related to liability and compensation for marine pollution damage) is presented in Table 5. Precisely, the first criterion diversifies prevention of maritime accidents and sea pollution and prevention of sea pollution from/to ships by the type of pollution. The first level comprises international regulations aimed at preventing maritime accidents (including marine pollution). The second level refers to marine pollution prevention according to certain types of pollution from/to ships. 
Table 5. Global legal framework and adoption status of Montenegro.

\begin{tabular}{|c|c|c|}
\hline Relevant Regulations & Name & Adoption Status \\
\hline Global & $\begin{array}{l}\text { The United Nations Convention on the Law of the Sea, } \\
\text { UNCLOS } 1982\end{array}$ & Ratified \\
\hline \multirow{11}{*}{ Prevention of maritime accidents and sea pollution } & Relevant regulations by criteria I, II, and III & \\
\hline & I Prevention & \\
\hline & $\begin{array}{l}\text { The International Convention for the Safety of Life at Sea, } \\
\text { SOLAS } 1974\end{array}$ & Ratified \\
\hline & $\begin{array}{l}\text { The International Convention for the Prevention of } \\
\text { Pollution from Ships, MARPOL 1973/1978 }\end{array}$ & Ratified \\
\hline & $\begin{array}{l}\text { The International Convention on Standards of Training, } \\
\text { Certification and Watchkeeping for Seafarers, STCW } 1978\end{array}$ & Ratified \\
\hline & $\begin{array}{l}\text { The International Convention on Load Lines, LL } 1966 . \\
\text { Protocol of } 1988\end{array}$ & Ratified \\
\hline & $\begin{array}{l}\text { The International Convention on Tonnage Measurement of } \\
\text { Ships, TONNAGE } 1969\end{array}$ & Ratified \\
\hline & The International Convention for Safe Containers, CSC 1972 & Ratified \\
\hline & $\begin{array}{l}\text { The Convention on the International Regulations for } \\
\text { Preventing Collisions at Sea, COLREG } 1972\end{array}$ & Ratified \\
\hline & $\begin{array}{l}\text { The Convention on Facilitation of International Maritime } \\
\text { Traffic, FAL } 1965\end{array}$ & Ratified \\
\hline & $\begin{array}{l}\text { The Convention on the International Maritime Satellite } \\
\text { Organization, INMARSAT } 1976\end{array}$ & Not ratified \\
\hline \multirow{12}{*}{$\begin{array}{l}\text { Prevention of sea pollution from/to ships by the type } \\
\text { of pollution }\end{array}$} & $\begin{array}{l}\text { The Convention on the Prevention of Marine Pollution by } \\
\text { Dumping of Wastes and Other Matter, LC } 1972\end{array}$ & Ratified \\
\hline & $\begin{array}{l}\text { The International Convention on the Control of Harmful } \\
\text { Anti-fouling Systems on Ships, AFS } 2001\end{array}$ & Ratified \\
\hline & $\begin{array}{l}\text { The International Convention for the Control and } \\
\text { Management of Ships' Ballast Water and Sediments, BWM } \\
2004\end{array}$ & Ratified \\
\hline & $\begin{array}{l}\text { The International Convention for the Safe and } \\
\text { Environmentally Sound Recycling of Ships, HONG KONG } \\
\text { Convention, } 2009\end{array}$ & Not ratified \\
\hline & \multicolumn{2}{|c|}{ II Legal framework to eliminate and reduce harmful consequences } \\
\hline & $\begin{array}{l}\text { The International Convention on Maritime Search and } \\
\text { Rescue, SAR } 1979\end{array}$ & Ratified \\
\hline & The International Convention on Salvage, SALVAGE 1989 & Ratified \\
\hline & $\begin{array}{l}\text { The International Convention Relating to Intervention on } \\
\text { the High Seas in Cases of Oil Pollution Casualties, } \\
\text { INTERVENTION } 1969\end{array}$ & Ratified \\
\hline & $\begin{array}{l}\text { Protocol relating to Intervention on the High Seas in Cases } \\
\text { of Pollution by Substances Other Than Oil, } \\
\text { INTERVENTION PROT } 1973\end{array}$ & Ratified \\
\hline & $\begin{array}{l}\text { The International Convention on Oil Pollution } \\
\text { Preparedness, Response and Cooperation, OPRC } 1990\end{array}$ & Not ratified \\
\hline & $\begin{array}{l}\text { Protocol of Preparedness, Response and Co-operation to } \\
\text { Pollution Incidents by Hazardous and Noxious Substances, } \\
\text { OPRC/HNS } 2000\end{array}$ & Not ratified \\
\hline & \multicolumn{2}{|c|}{$\begin{array}{l}\text { III Legal framework related to liability and compensation for marine } \\
\text { pollution damage }\end{array}$} \\
\hline
\end{tabular}


Table 5. Cont.

\begin{tabular}{|c|c|c|}
\hline Relevant Regulations & Name & Adoption Status \\
\hline & $\begin{array}{l}\text { The International Convention on Civil Liability for Oil } \\
\text { Pollution Damage, CLC 1969, CLC Protocols } 1976 \\
\text { CLC Protocol } 1992\end{array}$ & $\begin{array}{l}\text { Not ratified } \\
\text { Ratified }\end{array}$ \\
\hline & $\begin{array}{l}\text { The International Convention on the Establishment of an } \\
\text { International Fund for Compensation for Oil Pollution } \\
\text { Damage, FUND 1971, FUND Protocols } 1976 \\
\text { FUND Protocol } 1992 \text { and FUND Protocol } 2003\end{array}$ & $\begin{array}{l}\text { Not ratified } \\
\text { Ratified }\end{array}$ \\
\hline & $\begin{array}{l}\text { The Convention relating to Civil Liability in the Field of } \\
\text { Maritime Carriage of Nuclear Material, NUCLEAR } 1971\end{array}$ & Not ratified \\
\hline & $\begin{array}{l}\text { The Convention on Limitation of Liability for Maritime } \\
\text { Claims, LLMC 1976, Protocol } 1996\end{array}$ & Not ratified \\
\hline & $\begin{array}{l}\text { The Athens Convention relating to the Carriage of } \\
\text { Passengers and their Luggage by Sea, PAL 1974, PAL } \\
\text { Protocols, 1976, PAL Protocol } 1990 \\
\text { PAL Protocol } 2002\end{array}$ & $\begin{array}{l}\text { Not ratified } \\
\text { Ratified }\end{array}$ \\
\hline & $\begin{array}{l}\text { The International Convention on Liability and } \\
\text { Compensation for Damage in connection with the Carriage } \\
\text { of Hazardous and Noxious Substances by Sea, HNS 1996, } \\
\text { Protocol, } 2010\end{array}$ & Not ratified \\
\hline & $\begin{array}{l}\text { The International Convention on Civil Liability for Bunker } \\
\text { Oil Pollution Damage, BUNKERS } 2001\end{array}$ & Ratified \\
\hline & $\begin{array}{l}\text { The International Convention on the Removal of Wrecks, } \\
\text { WRC } 2007\end{array}$ & Not ratified \\
\hline \multirow[t]{2}{*}{ Regional instruments } & $\begin{array}{l}\text { The Convention for the Protection of the Marine } \\
\text { Environment and the Coastal Region of the Mediterranean, } \\
\text { Barcelona Convention, } 1995\end{array}$ & Ratified \\
\hline & $\begin{array}{l}\text { The Paris Memorandum of Understanding on Port State } \\
\text { Control, Paris MoU } 1982\end{array}$ & Ratified \\
\hline
\end{tabular}

The second criterion contains international regulations already adopted to eliminate and reduce the harmful consequences of maritime accidents that have already occurred. The third criterion reports the legal framework for determining liability and compensation for marine pollution damage at the international level. In addition to the global legal framework, Table 5 also recognizes two regional instruments by whose regional cooperation is realized for resolving specific issues in marine protection. It also shows the status of Montenegro concerning international conventions.

Although the subject of this paper does not allow the closer analysis of the global legal framework, in the next section we opted for a more detailed presentation of the provisions of national legislation in the field of marine protection. We believe that any domestic legislation, including Montenegro, represents an important component contributing to the global legal regime and its environmental protection.

\subsection{National Regulations}

This section presents the Montenegrin legal framework on the protection of the sea from pollution from ships. Legal regulations are divided according to the three criteria starting with laws that deal with marine environment protection issues. Second are laws that treat different relations in the maritime sector, but in certain parts also regulate the protection of the sea from pollution. Last are laws that are directly related to the prevention of marine pollution. The Montenegrin legal framework is shown in Table 6. 
Table 6. Legal framework in Montenegro.

\begin{tabular}{|c|c|}
\hline National Regulations by Criteria I, II, and III & \\
\hline \multicolumn{2}{|l|}{ I Marine protection } \\
\hline \multirow{2}{*}{ Laws related to nature and environmental protection } & Law on Nature Protection, 2016 \\
\hline & Law on Environment, 2016 \\
\hline \multirow{3}{*}{ Laws on maritime transport } & Law of the Sea, 2007 \\
\hline & Law on Ports, 2008 \\
\hline & Law on Yachts, 2007 \\
\hline II Indirect impact on marine protection & Law on Maritime Navigation Safety, 2013 \\
\hline \multirow{2}{*}{$\begin{array}{l}\text { III Specialized regulation for marine protection caused by } \\
\text { pollution from vessels }\end{array}$} & Law on the Prevention of Sea Pollution from Vessels, 2011 \\
\hline & $\begin{array}{l}\text { National Plan for Emergent Reaction in the Event of Sea } \\
\text { Pollution from Vessels, } 2011\end{array}$ \\
\hline
\end{tabular}

The Law on Nature Protection [67] and the Law on Environment [68] refer to the protection and preservation of nature, and the environment, respectively. The marine environment is treated as a part of nature or the environment. These regulations have a general approach when formulating legal provisions concerning the protection of the marine environment. It is expected to have in mind their general character and the main objective related to environmental protection.

The Law on Nature Protection [67] protects marine habitats by a general provision, in the manner that prohibits the performance of actions and activities for destroying them (Article 19 of the Law). The need for the adoption of the Strategy on Marine Environmental Protection following Article 29 of the Law and providing the protection of the sea and coastal area by systematic monitoring of marine and coastal ecosystems including the implementation of specific measures are foreseen in the Law on Environment (Article 18 of the Law) [68].

The Law of the Sea, Law on Ports, Law on Yachts, and the Law on the Exploration and Production of Hydrocarbons belong to the maritime transport regulations which in certain parts regulate the protection of the sea from pollution [69]. In that sense, the Law of the Sea stipulates the duty for Montenegro to protect, preserve and improve the marine environment (Article 2 paragraph 3 of the Law). The Law envisages and encourages the cooperation of Montenegro with neighboring countries and countries in the region to prevent and reduce marine pollution as provided in Article 2, paragraphs 4 and 5 of the Law. Observing the Law of the Sea, it can be noticed that the provisions on the protection of the sea from pollution are contained in specific articles, which regulate the right of innocent passage and certain maritime zones [69].

Law on Ports and Law on Yachts represent the general laws that deal with the marine environment protection throughout several provisions thereof. According to Article 26 of the Law on Ports, to prevent pollution of the sea or the port area, the port beneficiary is obliged to adequately equip the port with facilities for receiving and handling waste. When natural persons or legal entities pollute the sea, the competent authorities shall inform them to terminate the pollution by removing the harmful effects.

According to Article 33 of the Law on Yachts [65], besides the nationality, identification, registration, and other issues, the article also regulates the provisions on marine pollution prevention from yachts. Article 28 stipulates the obligation for the master or yacht manager to immediately notify the administrative body about the eventual discharge of oil and oily water, waste, garbage, and other polluting substances including the exact position of the yacht.

The Law on Maritime Navigation Safety [32] is classified as a second criterion of the legal regime for marine protection in Montenegro. Its regulations indirectly impact the marine protection environment. The Law comprises all the aspects of maritime safety 
besides contributing to avoiding maritime accidents and related pollution of the sea. Concerning the protection of the sea from pollution, the provisions on Port State Control given in Part XIV, Articles 183 to 198 of the Law, are particularly significant.

The third criterion includes regulations on sea pollution protection from vessels, including those on pollution prevention [69]. These are the Law on the Prevention of Sea Pollution from Vessels [70] and the National Plan for Emergent Reaction in the Event of Sea Pollution from Vessels [71]. For the first time in the national framework, the Law regulates the segments of sea pollution protection from vessels. Its adoption aims to prevent, reduce and eliminate sea pollution as much as possible. The law regulates the sea pollution protection from vessels that navigate or are located in the inland waterways and the territorial sea of Montenegro. While observing, the lawmaker, when formulating its provisions, tries to implement the international obligations from numerous international conventions.

The Law includes: Part I (General Provisions), Part II (Pollution from the vessels), Part III (Ship for the transport of oil as load or as a fuel), Part IV (Ship for the transport of harmful liquids in bulk), Part V (Ship for the transport of harmful substances in the packaged form), Part VI (Fecal waste), Part VII (Communal waste), Part VIII (The emission of harmful substances into the air), Part IX (Ballast waters), Part X (System anti-fouling ship plating), Part XI (International dumping of the waste), Part XII (Reception and handling of waste, waste oil, cargo residues and sediment from ballast tanks in ports), and Part XIII (Responsibility and compensation in case of marine pollution from the vessels).

In April 2011 the Government of Montenegro brought the National Plan for Emergent Reaction in the Event of Sea Pollution from Vessels [71]. The Plan determines the main principles of actions, tasks, and obligations, together with measures to prevent, minimize or remove the consequence of the vessel-sourced marine pollution. The main goal of the Plan is to provide a prompt and efficient response to accidents of sea pollution from vessels at the national level. The Plan will be applicable in a maritime accident that has caused or could have caused pollution in the sea areas, both on the seabed or under the seabed including internal waters and territorial sea. The general aim of the Plan is to adequately react and provide an initial and efficient response in the case of oil spills, and discharge of harmful substances that adversely affect or could negatively impact the marine environment of Montenegro and its coasts, as well as to ensure the national and international cooperation in the Adriatic and Mediterranean Seas.

\section{Conclusions and Recommendations}

The concept of the BE is relatively new and appears as a "pillar of protection" for the unsustainable use of marine resources. Its relevance is mostly conditioned by the geographical position of the country and by the availability of marine and coastal potentials. The geographical position of Montenegro implies that the marine resources and potentials for Blue Growth represent its development opportunity. The question is, what is the approach of Montenegro towards BE, and does it observe marine resources as a potential for its growth and development?

Reviewed studies, likewise strategic documents and legislation in this area, address certain issues within BE. Numerous relevant documents indicated the lack of identified sectors, institutional structures, databases relevant for reviewing the current situation in the BE sectors, and scientific monitoring of marine resources management.

This research indicates that Montenegro is more oriented declarative to the sustainable development of marine resources and the BE concept progress. Although certain problems have been identified in the strategic documents, it is clear that the analysis for overcoming the problems in the sense of proposing concrete measures and solutions is missing. In our opinion, this will be especially evident during the realization of strategic goals. Although strategic documents identified certain problems, it is clear that the directions for solving the issues (i.e., proposing concrete measures) are missing. Nevertheless, this will be especially evident during the realization of strategic goals. However, we notice that implementation 
is still pending (given the recent adoption of these strategies), so deeper economic analysis will be the subject of another research.

Based on the conducted research in this paper, we give some general directions in order to provide more efficient marine resources monitoring in the country:

- Initiating a comprehensive survey in the manner of assessing the existing capacities of individual marine resources and determining their optimal level and intensity of exploitation;

- Establish coordinated cross-sectoral management in BE and maximum public involvement;

- Provide the efficient and effective implementation of legal regulations within the sector of maritime transport and further implementation of international instruments, especially in the part of the protection of the marine environment would avoid degradation of marine areas and the visual appearance of the coast;

- Forming an electronic database system relevant to the BE sectors and thinking in the direction of adopting a strategic document, e.g., Strategy on sustainable use of marine resources that would define and in detail describe all issues important for the Montenegrin BE development;

- Detailed economic analysis on determining the profit from the exploitation of marine resources and their participation in GDP and;

- Popularization of the BE concept through strengthening human resources in the context of higher education, vocational training, and raising public awareness.

All mentioned with the existence of a stable political environment oriented towards the development of the $\mathrm{BE}$ and favoring the importance of marine resources for the economic and general development of Montenegrin society, hopefully, represents a core basis for creating an environment focused on sustainably using marine resources and reducing the environmental impact of their use.

Author Contributions: Conceptualization, J.N. and M.Šs; methodology, J.N.; investigation, J.N. and M.Š.; resources, J.N. and M.Š.; data curation, J.N. and M.Š.; writing—original draft preparation, J.N.; writing—review and editing, J.N. and M.Š.; visualization, J.N.; supervision, J.N. Both authors have read and agreed to the published version of the manuscript.

Funding: This research was partially funded by the Sustainable development of BLUE economies through higher education and innovation in Western Balkan Countries project (BLUEWBC), Grant Agreement no. 2019-2009/001-001, Ref. no. 609693-EPP-1-2019-1-NO-EPPKA2-CBHE-JP of the Erasmus + program where the Faculty of Maritime Studies Kotor of the University of Montenegro acts as a partner in the project.

Conflicts of Interest: The authors declare no conflict of interest.

\section{References}

1. Petrick, K.; Fosse, J.; Lammens, H.; Fiorucci, F. Blue Economy in the Mediterranean; Union for the Mediterranean: Barcelona, Spain, 2017.

2. BLUEMED Italian White Paper Working Group. The BLUEMED Italian White Paper: An Overview of Relevance, Obstacles and Proposals of the Key Sectors for a Blue Growth; CNR Edizioni: Rome, Italy, 2018. [CrossRef]

3. Bennett, N.J.; Cisneros-Montemayor, A.M.; Blythe, J.; Silver, J.J.; Singh, G.; Andrews, N.; Calò, A.; Christie, P.; Di Franco, A.; Finkbeiner, E.M.; et al. Towards a sustainable and equitable blue economy. Nat. Sustain. 2019, 2, 991-993. [CrossRef]

4. Kildow, J.; McIlgorm, A. The importance of estimating the contribution of the oceans to national economies. Mar. Policy 2010, 34, 367-374. [CrossRef]

5. Colgan, C.S. The ocean economy of the United States: Measurement, distribution, \& trends. Ocean Coast. Manag. 2013, 71, 334-343. [CrossRef]

6. Niavis, S.; Papatheochari, T.; Kyratsoulis, T.; Coccossis, H. Revealing the potential of maritime transport for 'Blue Economy' in the Adriatic-Ionian Region. Case Stud. Transp. Policy 2017, 5, 380-388. [CrossRef]

7. Silver, J.J.; Gray, N.J.; Campbell, L.M.; Fairbanks, L.W.; Gruby, R.L. Blue Economy and Competing Discourses in International Oceans Governance. J. Environ. Dev. 2015, 24, 135-160. [CrossRef]

8. Hassanali, K. CARICOM and the blue economy-Multiple understandings and their implications for global engagement. Mar. Policy 2020, 120, 104137. [CrossRef] 
9. Pauli, G. The Blue Economy: 10 Years, 100 Innovations, 100 Million Jobs. Report to the Club of Rome; Paradigm Publications: Taos, NM, USA, 2010; ISBN 978-0912111902.

10. Henderson, J. Oceans without History? Marine Cultural Heritage and the Sustainable Development Agenda. Sustainability 2019, 11, 5080. [CrossRef]

11. Scholaert, F.; Margaras, V.; Pape, M.; Wilson, A.; Kloecker, C.A. The Blue Economy: Overview and EU Policy Frame-work-In Depth Analysis; European Parliament, European Parliamentary Research Service-ERPS: Brussels, Belgium, 2020.

12. Chen, S.; De Bruyne, C.; Bollempalli, M. Blue Economy: Community Case Studies Addressing the Poverty-Environment Nexus in Ocean and Coastal Management. Sustainability 2020, 12, 4654. [CrossRef]

13. Lee, K.-H.; Noh, J.; Khim, J.S. The Blue Economy and the United Nations' sustainable development goals: Challenges and opportunities. Environ. Int. 2020, 137, 105528. [CrossRef] [PubMed]

14. Andriamahefazafy, M.; Bailey, M.; Sinan, H.; Kull, C.A. The paradox of sustainable tuna fisheries in the Western Indian Ocean: Between visions of blue economy and realities of accumulation. Sustain. Sci. 2019, 15, 75-89. [CrossRef]

15. Christodoulou, A.; Woxenius, J. Sustainable Short Sea Shipping. Sustainability 2019, 11, 2847. [CrossRef]

16. Tirumala, R.D.; Tiwari, P. Innovative financing mechanism for blue economy projects. Mar. Policy 2020, 104194. [CrossRef]

17. European Commission. Report on the Blue Growth Strategy Towards More Sustainable Growth and Jobs in the Blue Economy; Commission Staff Working Document; European Comission: Brussels, Belgium, 2017.

18. WBUNDESA - World Bank and United Nations Department of Economic and Social Affairs. The Potential of the Blue Economy: Increasing Long-Term Benefits of the Sustainable Use of Marine Resources for Small Island Developing States and Coastal Least Developed Countries; World Bank: Washington DC, USA, 2017.

19. IMO. Nor-Shipping 2019-The Sustainable Development of a Blue Economy. International Maritime Organization. Available online: https:/ / www.imo.org/en/MediaCentre/SecretaryGeneral/Pages/NorShipping-2019.aspx (accessed on 10 December 2020).

20. European Union. The 2018 Annual Economic Report on EU Blue Economy, Maritime Affairs and Fisheries; European Commission: Brussels, Belgium, 2018.

21. EUNETMAR. Studies to Support the Development of Sea-Basin Cooperation in the Mediterranean, Adriatic and Ionian, and Black Sea, Report 2-Analysis to Support the Elaboration of the Adriatic and Ionian Maritime Action Plan; European Commission: Brussels, Belgium, 2014.

22. EUSAIR. EU Strategy for the Adriatic-Ionian Region. 2017. Available online: https://www.adriatic-ionian.eu/ (accessed on 4 December 2020).

23. SDMI-Strategy for the Development of Maritime Industry for the Period 2020-2030; Government of Montenegro, Ministry of Transport and Maritime Affairs: Podgorica, Montenegro, 2020.

24. NSSD—National Strategy for Sustainable Development until 2030; Government of Montenegro, Ministry of Sustainable Development and Tourism: Podgorica, Montenegro, 2016.

25. NSICAM-National Strategy for Integrated Coastal Area Management; Government of Montenegro, Ministry of Sustainable Development and Tourism: Podgorica, Montenegro, 2014.

26. TRDS-Transport Development Strategy-Montenegro 2019-2035; Government of Montenegro Ministry of Transport and Maritime Affairs: Podgorica, Montenegro, 2019.

27. NSDS-National Sustainable Development Strategy; Government of Montenegro, Ministry of Tourism and Environmental Protection: Podgorica, Montenegro, 2007.

28. FS-Fisheries Strategy of Montenegro 2015-2020; Government of Montenegro, Ministry of Agriculture and Rural Development: Podgorica, Montenegro, 2015.

29. TDS-Tourism Development Strategy in Montenegro until 2020; Government of Montenegro, Ministry of Tourism and Environmental Protection: Podgorica, Montenegro, 2008.

30. EDS-Energy Development Strategy of Montenegro to 2030; Government of Montenegro, Ministry of Economy: Podgorica, Montenegro, 2014.

31. MONSTAT. Statistical Office of Montenegro, Database and Reports on Traffic. Available online: https://www.monstat.org/cg/ page.php?id=36\&pageid=36 (accessed on 11 December 2020).

32. Law on Maritime Navigation Safety. Official Gazette of Montenegro, Nos. 62/13, 6/14, 47/15, 34/2019 and 77/2020.

33. EUNETMAR. Studies to Support the Development of Sea-basin Cooperation in the Mediterranean, Adriatic and Ionian, and Black Sea. Report 1-Analysis of Blue Growth Needs and Potential per Country; European Commission: Brussels, Belgium, 2014.

34. RDS-Regional Development Strategy of Montenegro 2014-2020; Government of Montenegro, Ministry of Economy: Podgorica, Montenegro, 2014.

35. MONSTAT. Statistical Office of Montenegro, Database and Reports on Fisheries. Available online: https://www.monstat.org/cg/ page.php?id=162\&pageid=162 (accessed on 11 November 2020).

36. Cobani, M.; Dragičević, B.; Dulčić, J.; Gambino, M.; Giovanardi, O.; Grati, F.; Grgičević, R.; Ikica, Z.; Joksimović, A.; Kolitari, J.; et al. Small-scale Fisheries in the Adriatic Sea: Information Gaps at Biological, Socio-economic and Environmental Level. In Proceedings of the First Regional Symposium on Sustainable Small-Scale Fisheries in the Mediterranean and Black Sea, St. Julian's, Malta, 27-30 November 2013. List of abstracts, 5-6.

37. Grati, F.; Aladzuz, A.; Azzurro, E.; Bolognini, L.; Carbonara, P.; Çobani, M.; Domenichetti, F.; Dragicevic, B.; Dulcic, J.; Đurovic, M.; et al. Seasonal dynamics of small-scale fisheries in the Adriatic Sea. Mediterr. Mar. Sci. 2018, 19, 21-35. [CrossRef] 
38. Rajović, G.; Bulatović, J. Geographical View of the Fisheries of Montenegro: Overview. Larhyss J. 2017, 29, 167-186.

39. Joksimović, A.; Pešić, A.; Đurović, M.; Ikica, Z.; Marković, O.; Mandić, M. The state of marine fisheries in Montenegro in the last 15 years. Studia Mar. 2019, 32, 12-22. [CrossRef]

40. Matić-Skoko, S.; Tutman, P.; Pešić, A.; Stagličić, N.; Marković, O.; Mandić, M.; Đurović, M.; Dulčić, J.; Joksimović, A.; Dragičević, B.; et al. A comparative approach to the Croatian and Montenegrin small-scale fisheries (SSF) in the coastal eastern Adriatic Sea. Acta Adriat. 2017, 58, 459-480. [CrossRef]

41. Joksimović, D.; Perošević, A.; Castelli, A.; Pestorić, B.; Šuković, D.; Đurović, D. Assessment of heavy metal pollution in surface sediments of the Montenegrin coast: A 10-year review. J. Soils Sediments 2020, 20, 2598-2607. [CrossRef]

42. Law on Marine Fisheries and Mariculture. Official Gazette of Montenegro, No. 56/09, and 47/15.

43. Law on Freshwater Fisheries and Aquaculture. Official Gazette of Montenegro, No. 17/08.

44. MHA-Montenegrin Hydrocarbons Administration; Work Report for 2019; Government of Montenegro: Podgorica, Montenegro, 2020; Work Report for 2019.

45. Law on Exploration and Production of Hydrocarbons. Official Gazette of Montenegro, Nos. 1/10 and 40/11, 62/13.

46. Law on Tax on Hydrocarbons. Official Gazette of Montenegro, No. 31/14.

47. Directive 2013/30/EU of the European Parliament and of the Council of 12 June 2013 on Safety of Offshore Oil and Gas Operations and Amending Directive 2004/35/EC, OJ L 178, 28.6.2013; European Comission: Brussels, Belgium, 2013.

48. Ministry of Economy. Announcement on the Workshop on the Use of Liquefied Natural Gas. 2020. Available online: https: //mek.gov.me/vijesti/220383/Ministarka-Sekulic-otvorila-Radionicu-o-koriscenju-tecnog-prirodnog-gasa.html (accessed on 19 December 2020).

49. Nikolić, D.; Gagić, R.; Ivošević, Š. Estimation of Air Pollution from Ships in the Boka Kotorska Bay. In The Handbook of Environmental Chemistry; Springer International Publishing: Cham, Switzerland, 2016; pp. 117-128, Springer International Publishing: Cham, Switzerland, 2016.

50. Dragović, B.; Tzannatos, E.; Tselentis, V.; Meštrović, R.; Škurić, M. Ship emissions and their externalities in cruise ports. Transp. Res. Part D Transp. Environ. 2018, 61, 289-300. [CrossRef]

51. Nikcevic, J. Montenegro on the Path to Paris MoU Accession: Towards Achieving a Sustainable Shipping Industry. Sustainability 2018, 10, 1900. [CrossRef]

52. Nikčević, J. Strengthening the role of local government to ensure sustainable development of the cruise sector: The case of Kotor. Mar. Policy 2019, 109, 103693. [CrossRef]

53. Škurić, M.; Maraš, V.; Davidović, T.; Radonjić, A. Optimal allocating and sizing of passenger ferry fleet in maritime transport. Res. Transp. Econ. 2020, 100868. [CrossRef]

54. Škurić, M.; Maraš, V.; Radonjić, A.; Gagić, R.; Nikolić, D. Some Results of Air Pollution from Passenger Ferries in the Boka Kotorska Bay. In The Handbook of Environmental Chemistry; Springer International Publishing: Cham, Switzerland, 2020; pp. 1-23.

55. Ivanovic, Z.; Bauk, S. Multiphase Approach to Developing Model of Logistics for Coastal Tourist Destinations. Promet. Traffic Transp. 2014, 26, 405-418. [CrossRef]

56. Vitić-Ćetković, A.; Bauk, S. E-Services and Positioning of Passenger Ports in the Context of Cruise Tourism Promotion. Promet. Traffic Transp. 2014, 26, 83-93. [CrossRef]

57. Bauk, S.; Calvo, J.A.L.; Schmeink, A.; Azam, S.; Mathar, R. On deploying vehicular communication at the developing seaport and related innovation success impediments. Transportation 2019, 34, 126-134. [CrossRef]

58. Kapidani, N.; Bauk, S.; Davidson, I. Digitalization in Developing Maritime Business Environments towards Ensuring Sustainability. Sustainability 2020, 12, 9235. [CrossRef]

59. Nikčević, J. A Decade of the Montenegrin Maritime Legislation. In Proceedings of the 18th International Conference on Transport Science, Portorož, Slovenia, 14-15 June 2018.

60. Official Site of the Port of Adria. Available online: https://www.portofadria.me/ (accessed on 3 January 2021).

61. Official Site of the Port of Bar AD. Available online: https://www.lukabar.me/index.php/me/o-nama/istorijat-luke (accessed on 4 January 2021).

62. Financial Reports of the Port of Bar. Consolidated Financial Reports of the Port of Bar, Partial Information. 2019. Available online: https: / / www.lukabar.me/index.php/me/508-profit-luke-bar-duplo-veci-nego-lani (accessed on 4 January 2021).

63. Caballe, J.; Lohrum, A.; Valls, S. Cruise Activities in MedCruise Ports: Statistics Report; MedCruise Association: Santa Cruz de Tenerife, Spain, 2020.

64. Financial Reports of the Port of Kotor. Consolidated Financial Reports of the Port of Kotor; MV KONSALT D.O.O.: Podgorica, Montenegro, 2019.

65. Law on Yachts. Official Gazette of Republic of Montenegro, Nos. 46/07, 73/10, 40/11 and 42/15.

66. Nikčević, G.J. Legal Status of Yachts in Montenegro. In Proceedings of the 5th International Maritime Science Conference, 21-29, Solin, Croatia, 22-23 April 2013.

67. Law on Nature Protection. Official Gazette of Montenegro, No. 54/16.

68. Law on Environment. Official Gazette of Montenegro, No. 52/16.

69. Nikčević, J.; Mandić, N. Legal Regime for the Protection of the Marine Environment Against Pollution from Vessels in Montenegrin Adriatic Waters. In The Handbook of Environmental Chemistry; Springer Science and Business Media LLC: Cham, Switzerland, 2021; pp. 1-25. 
70. Law on the Prevention of Sea Pollution from Vessels. Official Gazette of Montenegro, Nos.20/11, 26/11 and 27/14.

71. Ministry of Transport and Maritime Affairs of Montenegro. National Plan for Emergent Reaction in the Event of Sea Pollution from Vessels; Ministry of Transport and Maritime Affairs of Montenegro: Podgorica, Montenegro, 2011. 